学術論文

\title{
小球を一つ用いた球面減速機の出力球の回転計測
}

\section{Measurement of rotation of output ball in a spherical speed reducer using one small ball}

\author{
角南 尚幸 ${ }^{* 1}$ (学生員), 五福 明夫 ${ }^{* 1}$, 矢野 智昭 ${ }^{* 2}$ (会員), 笠島 永吉*3
}

\author{
Naoyuki SUNAMI(Stu. Mem.), Akio GOFUKU, Tomoaki YANO (Mem.), Nagayoshi KASASHIMA
}

\begin{abstract}
In order to construct a system with multi-degree of freedom by only using the motors with one degree of freedom, the same number of motors as the degree of freedom is required. On the other hand, in a spherical motor with three degrees of freedom, it is possible to realize a system with three degrees of freedom by only one spherical motor, and it is possible to reduce the size of the system. However, in many spherical motors driven by electromagnets, a spherical speed reducer is required as a device to extract and transmit the output torque. The spherical speed reducer considered in this study is composed of an output ball and an intermediate small ball to transmit the torque from the rotor. In the mechanism of the spherical speed reducer, a model of the rotation transmission to control suitably the rotor is required for a desirable rotation of the output ball. The purpose of this study is to measure angular velocities of the small ball and the output ball in order to derive a rotation transmission model. The angular velocity of each ball is measured using two optical mouse sensors. From the measurement results, a valid rotation transmission model is derived.
\end{abstract}

Keywords: spherical speed reducer, rotation transmission model, optical mouse sensor

(2017 年 10 月 26 日受付, 2018 年 1 月 29 日再受付, 2018 年 3 月 22 日再々受付)

\section{1 緒言}

一般的に多自由度の回転を行う機械システムの実 現には 1 自由度のモータが用いられる。しかし, 近年 機械システムには, 柔軟な動きが求められており, 必 要とする自由度数は増加し続けている。通常の 1 自由 度のモータによる柔軟な動きの実現のためには，モー タの使用数が増えて, 機械システムは大型化, 複雑化 するという問題を有している。この問題に対処するた めに, 多自由度アクチュエータの研究が行われており ${ }^{[1]}$, その一つとして球面モータの実用化が期待されて いる[2,3]。

球面モータは一つで 3 自由度を持つため, 1 自由度 のモータの場合と比べてモータの使用数を減らせるこ とから，機械システムの小型化，軽量化が見込める。 また，球面モータは，各回転軸の回転中心が一致して いることにより，目標姿勢への制御を簡単化でき，組 夕付け誤差や難メンテナンス化による超高精度位置決 めシステムの実現への困難さの解消が可能である。そ して, 可動子部分が球体であることから, 余分な機構 を除いた直接的な駆動を実現可能という特徵[4]により，

\footnotetext{
連絡先: 角南 尚幸, $\bar{\top} 700-8530$ 岡山市北区津島中 3-1-1, 岡山大学大学院 自然科学研究科,

e-mail: pkbw1yhi@s.okayama-u.ac.jp

${ }^{* 1}$ 岡山大学 ${ }^{* 2} \mathrm{JAXA}{ }^{* 3}$ 産総研
}

ロボットの関節・眼, 攪汼機 ${ }^{[5]}$ 一の応用が見込まれてい る。その一方で, 電磁力を用いた球面モータの多くは, 高出力トルクの発生が困難という課題を持つ。この課 題を解決するための出力を増大する装置の一つとして, 球面減速機の開発が求められている。

筆者らは，これまでに小球が二つの球面減速機を検 討し, 球面モータの可動子と小球との間の回転伝達モ デルを求めた ${ }^{6]}$ 。しかしながら, 二つの小球と出力球と の間の回転伝達には，すべりが発生し，出力球を含め た理論的な回転伝達モデルは構築できていない。本研 究では，小球を二つ用いた球面減速機より単純な機構 において，すべりが発生しない条件で回転伝達モデル の導出が可能かを確かめるため, トルク伝達用の小球 一つと出力球一つから構成される球面減速機構を検討 する。この機構では, 一つの小球を球面モータの可動 子と出力球に接触させて, 各接点の摩擦力でトルクを 伝達させる。

球面減速機構の開発において, 減速比を求めるため に出力トルクを計測して計算值と比較するには, 出力 球の回転軸が明確である必要がある。しかし，球面モ 一タの可動子，球面減速機の小球や出力球はそれぞれ 点接触しており, 力の伝達過程は複雑である。そのた め，トルクを計測する前に球面減速機の出力球に所望 の回転をさせるための回転伝達モデルを構成する必要 がある。 
球の回転を角速度ベクトルで表すと, 回転伝達モデ ルによって可動子の角速度ベクトルから出力球の角速 度ベクトルを推定できる。そして, 逆に指定した出力 球の角速度ベクトルを与える可動子の角速度ベクトル を求めることができる。回転伝達モデルの作成には, 可動子の回転による球面減速機構における小球および 出力球の回転の計測が必要である。

そこで本論文では, 球面減速機構における小球と出 力球の回転の計測を行い, 回転伝達モデルの導出を目 的とした。本報告では可動子と小球, 出力球の回転の 計測実験を行った。そして, 可動子と出力球間におけ る回転伝達モデルの導出を試みた。

\section{2 球面減速機}

\section{1 先行研究}

矢野らは Fig. 1 のような球面減速機を試作した ${ }^{[7,8]}$ 。 この球面減速機は Fig. 2 のように球面モータの上に小 球, その小球の上に出力球を設置している。この球面 減速機も本研究で提案する球面減速機と同様, 摩擦に より可動子の回転を小球に伝え, その回転を出力球に 伝えて出力を取り出す。この機構では出力球の半径を 変更することで出力トルクを増幅することができる。 しかしながら, 先行研究では可動子から出力球までの 回転伝達モデルは導出されていない。

\section{2 試作した球面減速機の構成}

Fig. 3 に本研究で試作した球面減速機を示す。球面 モータの可動子は直径 $200 \mathrm{~mm}$ のアクリル球款であり [5], 球面減速機は球面モータの固定子に取り付ける。

出力球は直径 $200 \mathrm{~mm}$ のアクリル半球殼を二つ張り あわせて，摩擦係数を大きくするために表面をゴム系 骨材(安全地帯セーフステップ滑り止めスプレー)で塗 装した。出力球を可動子より大きくすることで減速効 果が得られるが，本論文では回転伝達モデルを検討す るため, 出力球と球面モータの可動子の直径を同じに した。したがって，この場合には減速効果は得られな い。

直径 $100 \mathrm{~mm}$ のアクリル半球殼を二つ張り合わせた 小球も, 摩擦係数を大きくするために表面を塗装した。 一つの小球だけでは出力球を支持できないため, Fig. 4 に示すような大型のボールキャスタを二つ配置した。

Fig. 5 には小球支持円盤を示す。小球支持円盤は直径 $300 \mathrm{~mm}$, 厚さ $10 \mathrm{~mm}$ のアクリルの円盤で, 中心が正

三角形の頂点に位置するように直径 $102 \mathrm{~mm}$ の 3 つの 円形の穴があけてあり，小球を最大 3 個まで配置でき る。大型のボールキャスタのボール先端は, Fig. 6 のよ うに小球と出力球の中心を通る直線に垂直で, 出力球 の中心を含む平面 $\mathrm{P}$ 上に配置している。Fig. 7 には, 小球支持円盤の円形穴の下に 2 つ配置した小型のボー ルキャスタを示す。この小型のボールキャスタにより， 小球が円形穴の縁に接触してその回転の障害となるこ とを防ぐことが可能である。 Fig. 7(a)は，小球支持円 盤の上から見た図である。Fig.7(b)では，小型のボール キャスタのボール先端を配置してある平面 $\mathrm{P}$ を示す。 Fig. 7(b)の平面 $\mathrm{P}$ も大型のボールキャスタと同様に, 可動子と小球の中心を通る直線に垂直で，小球の中心 を含む平面である。なお，予備実験より，ボールキャ スタによる摩擦が負荷となり，小球と出力球の回転へ 影響することが分かっている。Fig. 6, Fig. 7 の出力球 と小球を支持するボールキャスタの特殊な配置は，ボ 一ルキャスタによる出力球と小球の回転への影響が少 ない配置の一つである。

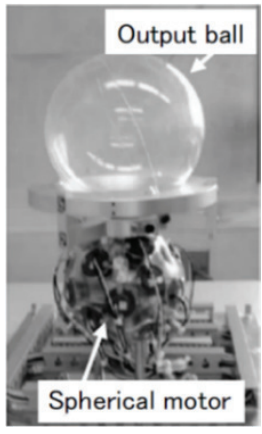

Fig. 1 Spherical speed reducer of related study in $\operatorname{AIST}^{[7]}$.

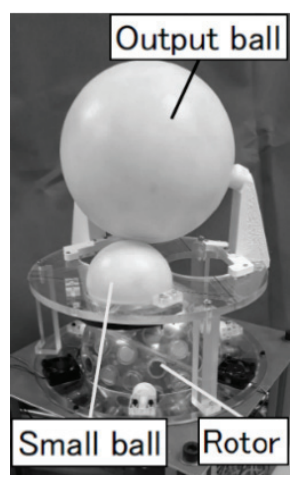

Fig. 3 Spherical speed reducer developed in this study.

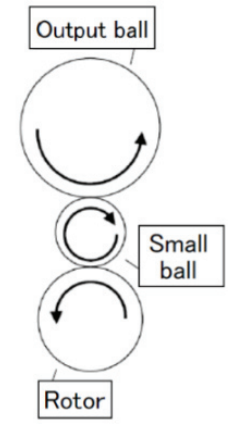

Fig. 2 Behavior of a spherical speed reducer in AIST.

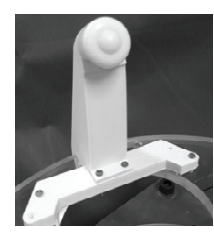

Fig. 4 Large ball caster.

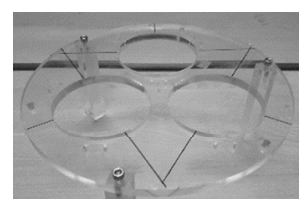

Fig. 5 Supporter of intermediate small balls. 


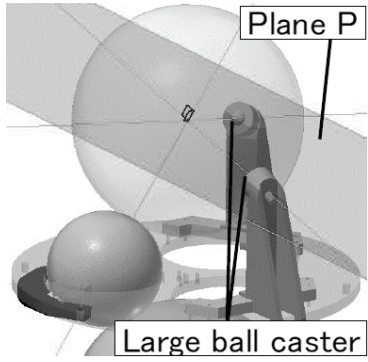

Fig. 6 Arrangement of two large ball casters.

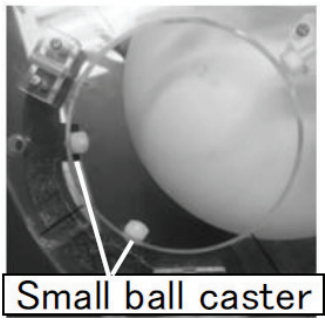

(a) Small ball casters

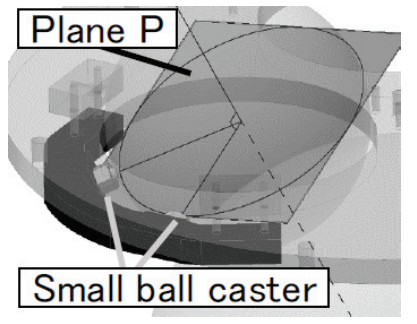

(b) Arrangement plane of small ball casters
Fig. 7 Arrangement of two small ball casters.

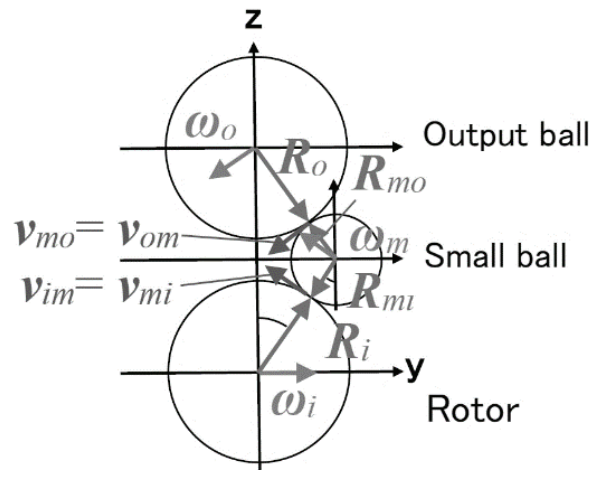

Fig. 8 Rotation vectors of rotor, small ball and output ball.

\section{3 回転伝達モデル}

本研究で提案する球面減速機構はトルク伝達用の 小球一つと出力球一つで構成される。このため, 球面 減速機における可動子と出力球間の回転伝達モデルは, 可動子から一つの小球への回転伝達モデルを表す関数 $f$ と, 小球から出力球への回転伝達モデルを表す関数 $g$ の合成関数 $g \circ f$ で表される。本論文では, 可動子と小 球間の回転伝達モデル $f$ と, 小球と出力球間の回転伝 達モデル $g$ を構築した。

小球が 1 つの場合の小球の角速度ベクトルを計測し た結果 ${ }^{[6]}$ から,「可動子と小球の接点における可動子と 小球の速度べクトルが等しい」ことが分かっている。 小球と出力球間の機構は, 可動子と小球間の機構と比 較して小球中心を含む水平面に対称的である。そのた
め,「可動子と小球の接点における可動子と小球の速度 ベクトルが等しい」と「小球と出力球の接点における 速度ベクトルが等しい」と仮定した。そして，球支持用 のボールキャスタの影響がない場合の理論的な回転伝達 モデルを構築した。

Fig. 8 に可動子と小球，出力球の角速度ベクトルを 示す。仮定に基づいて数学的に導いた，可動子の角速 度ベクトルを与えたときの小球の角速度べクトル，お よび出力球の角速度べクトルを式(2), (4)に示す。式(1) (4)において $\boldsymbol{\omega}_{i}, \boldsymbol{\omega}_{m}, \boldsymbol{\omega}_{o}$ はそれぞれ可動子，小球，出 力球の角速度ベクトルである。 $\boldsymbol{R}_{i}$ は可動子の中心から 可動子と小球の接点への位置ベクトルを示し， $\boldsymbol{R}_{m i}$ は 小球の中心から可動子と小球の接点への位置ベクトル を示している。そして， $\boldsymbol{R}_{m o}$ は小球の中心から小球と 出力球の接点への位置ベクトルを示し, $\boldsymbol{R}_{o}$ は出力球の 中心から小球と出力球の接点への位置ベクトルを示し ている。 $\boldsymbol{R}_{i}, \boldsymbol{R}_{m i}$ は，小球支持円盤にあいた円形の穴の 中心に, 小球の中心があるとして定めている。 $\boldsymbol{R}_{m o}$, $\boldsymbol{R}_{o}$ は， $\boldsymbol{R}_{m i}, \boldsymbol{R}_{i}$ の y z $\mathrm{z}$ 成分をそれぞれ逆向きにした ベクトルと定めている。また，可動子と小球の接点に おいて， $\boldsymbol{v}_{i m}$ は可動子表面での速度べクトルを示し， $\boldsymbol{v}_{m i}$ は小球表面での速度ベクトルを表す。小球と出力 球の接点において, $\boldsymbol{v}_{m o}$ は小球表面での速度べクトル を示し， $v_{\text {om }}$ は出力球表面での速度べクトルを表す。

$$
\begin{gathered}
\boldsymbol{v}_{i m}=\boldsymbol{v}_{m i}=\boldsymbol{\omega}_{i} \times \boldsymbol{R}_{i} \\
\boldsymbol{\omega}_{m}=\frac{\boldsymbol{R}_{m i} \times \boldsymbol{v}_{m i}}{\left|\boldsymbol{R}_{m i}\right|^{2}}=\frac{\boldsymbol{R}_{m i} \times\left(\boldsymbol{\omega}_{i} \times \boldsymbol{R}_{i}\right)}{\left|\boldsymbol{R}_{m i}\right|^{2}} \\
\boldsymbol{v}_{m o}=\boldsymbol{v}_{o m}=\boldsymbol{\omega}_{m} \times \boldsymbol{R}_{m o} \\
\boldsymbol{\omega}_{o}=\frac{\boldsymbol{R}_{o} \times \boldsymbol{v}_{o m}}{\left|\boldsymbol{R}_{o}\right|^{2}}=\frac{\boldsymbol{R}_{o} \times\left(\boldsymbol{\omega}_{m} \times \boldsymbol{R}_{m o}\right)}{\left|\boldsymbol{R}_{o}\right|^{2}}
\end{gathered}
$$

\section{4 球の角速度ベクトル計測}

\section{1 計測目的}

可動子のあらゆる回転に対して可動子と小球，出力 球の角速度ベクトルを計測し, 計測結果が式(2), (4)で 理論的に求まる小球と出力球の角速度ベクトルと一致 するかを検討する。そして，可動子と小球間の回転伝 達モデルと，小球と出力球間の回転伝達モデルを構築 することを目的とする。 

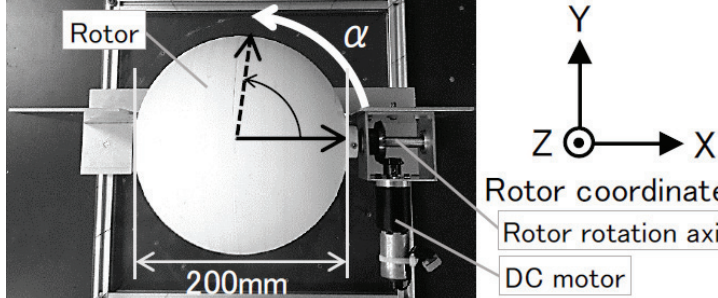

Rotor coordinates Rotor rotation axis DC motor

View from above

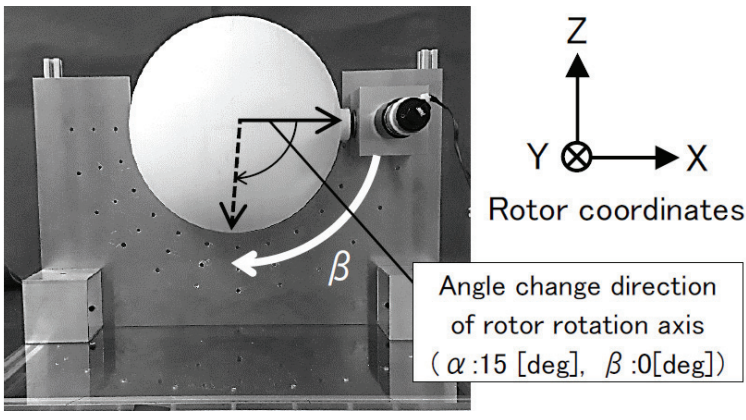

Front view

Fig. 9 Rotor driven by a DC motor.
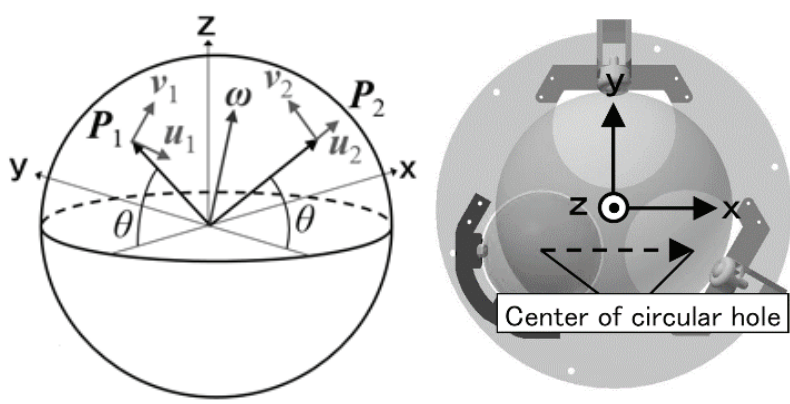

Fig. 10 Measurement base vectors and rotation vectors of a ball.

Table 1 Four patterns of angle change rotation axes of rotor rotation axis.

\begin{tabular}{c|c}
\hline Pattern & Angles of $\alpha$ and $\beta$ (deg) \\
\hline (1) & $\beta=0, \alpha=-180 \sim 180$ \\
(2) & $\alpha=0, \beta=-180 \sim 180$ \\
(3) & $\alpha=-60, \beta=-180 \sim 180$ \\
(4) & $\alpha=60, \beta=-180 \sim 180$ \\
\hline
\end{tabular}

式(2), (4)が，可動子のどの回転でも成立することを 示すには, 可動子のあらゆる回転に対して小球と出力 球の角速度ベクトルを計測し, 計測結果と式(2), (4)の 計算值を比較する必要がある。このため, Fig. 9 のよう な DC モータ駆動の可動子の回転機構を製作した。こ の機構では回転軸と角速度の大きさを正確に設定でき る。また，この機構では，回転軸を支えるアルミ角柱 をアルミ板上の穴で変更でき, アルミ板を支えるアル ミ角柱も下のアクリル板上の穴で $15 \mathrm{deg}$ ごとに回転し
て固定可能である。計測においては球面モータと置き 換えて用いた。

\section{2 計測方法}

センサの要求条件としては，本研究の球面減速機に 組み込むことが可能なセンサの大きさと非接触での計 測方法があり，その両方を満たす光学式のマウスセン サ(以下マウスセンサ)を採用した。マウスセンサを用 いる方法で, 球の角速度ベクトルの計測を行う[9]。マウ スセンサは，搭載したイメージセンサが反射光で読み 取った画像情報の変化から，周期的に 2 方向の移動量 (ポイント $/ \mathrm{mm}$ )を計算するものを指す。この実験では, 単位時間当たりの相対移動量を取得するため, マウス センサで生じる累積誤差が計測值へ与える影響は小さ いと判断した。

Fig. 10 に示すように, マウスセンサの位置ベクトル を $\boldsymbol{P}_{1}, \boldsymbol{P}_{2}$, マウスセンサの 2 方向の計測方向の単位心゙ クトルを $\boldsymbol{u}_{1}, \boldsymbol{v}_{1}, \boldsymbol{u}_{2}, \boldsymbol{v}_{2}$, 球の角速度ベクトルを $\boldsymbol{\omega}$, マウスセンサのそれぞれの計測方向で計測される球表 面の移動速さを $a_{1}, b_{1}, a_{2}, b_{2}$ とする。球の表面移動 量は球の角速度ベクトル $\boldsymbol{\omega}$ とそれぞれの位置ベクトル $\boldsymbol{P}_{1}, \boldsymbol{P}_{2}$ の外積で表される。 $a_{1}, b_{1}, a_{2}, b_{2}$ はその球の 表面移動量を表す心゙クトルと単位ベクトル $\boldsymbol{u}_{1}, \boldsymbol{v}_{1}, \boldsymbol{u}_{2}$, $\boldsymbol{v}_{2}$ の内積により求められる。 $a_{1}, b_{1}, a_{2}, b_{2}$ を助の各 成分について整理すると式(5)亡なる ${ }^{[9]}$ 。ここで， $r$ と $\theta$ はそれぞれ，球の半径と，Fig. 10 に示す角度である。

計測はマウスセンサで取得される相対移動量の合 計值を $500 \mathrm{~ms}$ ごとに取得し, 可動子の回転開始 1 秒後 から 25 秒間において，二つの小球それぞれの角速度 ベクトルの各成分を算出して記録する。球の角速度べ クトル山は, Fig. 10 のように二つのマウスセンサがそ れぞれ計測する 2 方向の微小時間の相対移動量から, 式(5)を用いて求まる。マウスセンサは一つの球に対し て二つずつ必要であるため, 小球と出力球に対して合 計 4 つ配置している。

可動子の回転軸方向は, 固定子座標系と可動子座標 系から z-y-z 系の才イラー角 $(\alpha, \beta, \gamma)$ で定める。固定子 座標系は，Fig. 11 の小球支持円盤の中心を座標系の原 点, 円盤上を xy 平面とした xyz 座標系である。小球支 持円盤の 2 つの円形穴中心を通る直線方向を $\mathrm{x}$ 軸とし ている。可動子座標系は, Fig.9 のように可動子の回転 軸を X 軸とした XYZ 座標系である。 $\alpha$ 角は $\mathrm{z}$ 軸周り に回転させた角度である。Fig. 9 は， $\alpha$ 角が $15 \mathrm{deg}$ の図 
となり, z 軸周りに-15 deg 回転させると, 固定子座標 系の $\mathrm{x}$ 軸と一致する。 $\alpha$ 角回転させた可動子座標系を $X^{\prime} Y^{\prime} Z^{\prime}$ 座標系とすると, $\beta$ 角は $Y^{\prime}$ 軸周りに回転させた 角度である。 $\gamma$ 角は 0 deg とする。そして, Table 1 の ように，4パターンの回転軸周りに可動子を回転させ る。各パターンでは $\alpha, \beta$ の片方を一定にし,もう片方 を $15 \mathrm{deg}$ ごとに変更する。そして, それぞれの可動子 の回転に対して, 小球と出力球の角速度ベクトルを計 測する。

なお，可動子の角速度の大きさの調整は，ロータリ エンコーダとオシロスコープを用いた。角速度の大き さは DC モータの電圧を変更することで波形の周期を 調節し, 一定 $(2.5 \mathrm{rad} / \mathrm{s})$ とした。計測結果は固定子座 標系における角速度ベクトルとする。

$$
\boldsymbol{\omega}={ }^{t}\left(-\frac{b_{2}}{r} \quad \frac{b_{1}}{r} \frac{1}{\cos \theta}\left(\frac{a_{2}}{r}-\frac{b_{1}}{r} \sin \theta\right)\right)
$$

\section{3 計測精度}

マウスセンサは光の反射距離が変化すると計測值 に誤差が生じる。DC モータ駆動の可動子を用いて, こ の実験で使用したマウスセンサの一つで光の反射距離 による誤差の検証を行った。検証条件は, DC モー夕駆 動の可動子の角速度の大きさを $2.5 \mathrm{rad} / \mathrm{s}$, 角度 $\alpha$ を 0 $\operatorname{deg}, \beta$ を $0 \mathrm{deg}$ とした。可動子の球中心を通り, 回転 軸に垂直な平面上の表面をマウスセンサで計測する。 そして, マウスセンサのイメージセンサの位置を球表 面から鉛直方向に移動させた。その検証の際, 光の反 射距離を $0.5 \mathrm{~mm}$ 程度前後させると, $\mathrm{DC}$ モー夕駆動の 可動子における角速度と比べて最大で $0.2 \mathrm{rad} / \mathrm{s}$ の誤差 が生じることが分かった。

この誤差により, 計測した角速度べクトルには, 最 大 $11 \mathrm{deg}$ 程度の誤差角度が発生する。誤差角度は, 大 きさが $2.5 \mathrm{rad} / \mathrm{s}$ の元の可動子の角速度ベクトルとの内 積から計算した角度差である。本研究で用いる球はそ の製作方法から完全な真球ではないと考えられ, 球表 面とマウスセンサとの光の反射距離が $0.5 \mathrm{~mm}$ 程度前 後することが考えられる。このため, 最大 $11 \mathrm{deg}$ 程度 の誤差角度をこの実験での計測許容誤差とした。

この実験の計測值と回転伝達モデルの理論值の比較 においては, 計測值が理論值とどの程度一致している かを検討することが目的である。そして，比較結果が 不一致だった場合には, $11 \mathrm{deg}$ 以下の誤差角度が誤差
原因特定に影響しないと考えられる。また，仮に球に

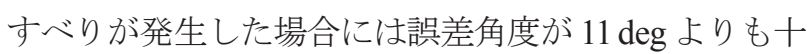
分に大きくなると考えられるため, この計測装置およ び方法で精度は十分とした。

\section{5 計測結果}

例として, 可動子が Table 1 のパターン(1)の場合の, 小球の角速度ベクトルにおける計測值と式(2)の計算 值を比較したグラフを Fig. 12(a)に示す。そして, 出力 球の角速度ベクトルにおける計測值と式(4)の計算值 を比較したグラフを Fig. 12 (b)に示す。また, 計測值は 回転開始から 25 秒間の 50 回分の平均值をプロットし ている。標準偏差はFig. 12(a)の小球の場合で $0.13 \mathrm{rad} / \mathrm{s}$, Fig. 12(b)の出力球の場合で $0.06 \mathrm{rad} / \mathrm{s}$ 程度である。他の パターンを含めた計測値と理論值の角度差の平均と最 大值は Table 2 に示す。角度差の平均は， $\alpha$ または $\beta$ を -180〜180 deg に変更した 24 通りの計測結果から求め た角度差の平均である。

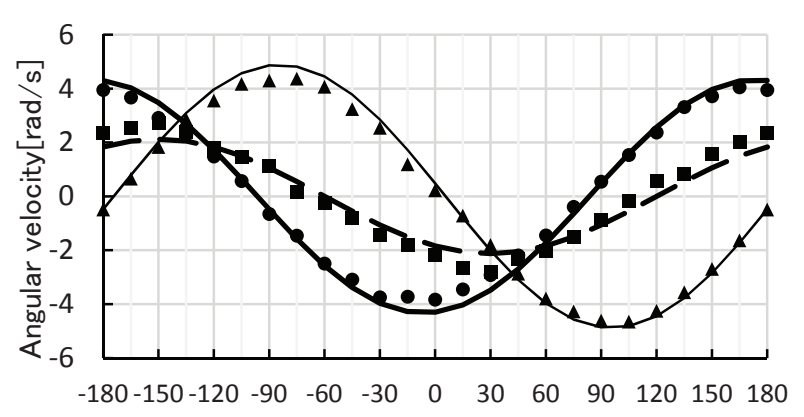

(a) Angular velocity vectors of small ball rotation

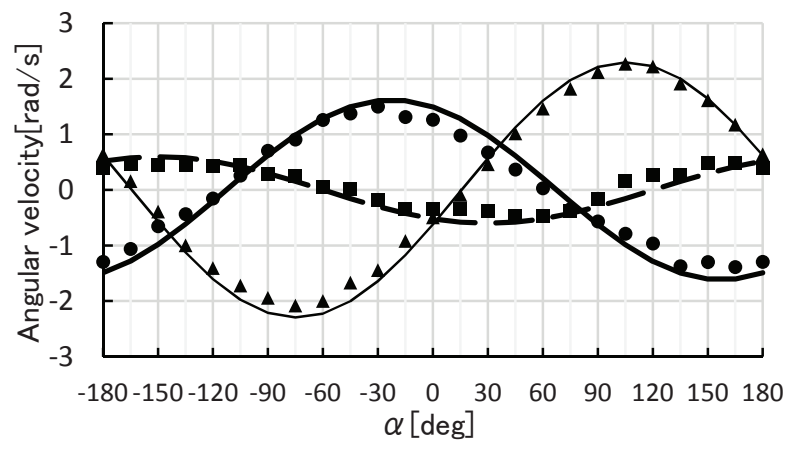

- $x$ element of measured angular velocity vector

- y element of measured angular velocity vector

- $z$ element of measured angular velocity vector

- $x$ element of theoretical angular velocity vector

- y element of theoretical angular velocity vector

— - z element of theoretical angular velocity vector

(b) Angular velocity vectors of output ball rotation Fig. 12 Comparisons of angular velocity vectors between calculated results from the rotation transmission model and measurement results. 
Table 2 Angular difference of each pattern

\begin{tabular}{c|c|c|c|c}
\hline \multirow{2}{*}{ Pattern } & \multicolumn{2}{|c|}{ Small ball } & \multicolumn{2}{c}{ Output ball } \\
\cline { 2 - 5 } & $\begin{array}{c}\text { Average } \\
\text { (deg) }\end{array}$ & $\begin{array}{c}\text { Max } \\
\text { (deg) }\end{array}$ & $\begin{array}{c}\text { Average } \\
\text { (deg) }\end{array}$ & $\begin{array}{c}\text { Max } \\
\text { (deg) }\end{array}$ \\
\hline (1) & 5.8 & 11.5 & 4.8 & 9.3 \\
(2) & 7.8 & 11.4 & 6.0 & 11.2 \\
(3) & 5.7 & 11.1 & 5.3 & 9.7 \\
(4) & 4.3 & 11.1 & 4.2 & 7.4 \\
\hline
\end{tabular}

\section{6 考察}

Fig. 12(a)のグラフから，式(2)で算出した小球の角速 度ベクトルと計測した角速度ベクトルがほぼ一致して いる。また, Fig. 12(b)のグラフから, 式(4)で算出した 出力球の角速度ベクトルと計測した角速度ベクトルも ほぼ一致している。Table 2 から Table 1 の各可動子回 転軸パターンにおいても, 角度差の最大值が $11 \mathrm{deg}$ 程 度と, 計測許容誤差程度で収まっている。計測結果か ら, 式(2), (4)の理論回転伝達モデルは, 小球が一つの 球面減速機構における球面モータの可動子と小球, 出 力球の回転の関係を表すことができると結論づけられ る。

以上から, 小球が一つの球面減速機構における球面 モータの可動子と出力球間における回転伝達モデルは, 式(2)，(4)の合成関数で式(6)と表される。

$$
\boldsymbol{\omega}_{o}=\frac{\boldsymbol{R}_{o} \times\left(\boldsymbol{R}_{\boldsymbol{m i}} \times\left(\boldsymbol{\omega}_{i} \times \boldsymbol{R}_{\boldsymbol{i}}\right) \times \boldsymbol{R}_{m o}\right)}{\left|\boldsymbol{R}_{m i}\right|^{2}\left|\boldsymbol{R}_{o}\right|^{2}}
$$

\section{7 結言}

本論文では，小球を一つ用いた球面減速機の回転伝 達モデル導出のために, 球面減速機構における小球と 出力球の角速度ベクトルの計測を行った。 すなわち, 各球に対して二つのマウスセンサから計測した球の表 面移動速度から角速度ベクトルを求めた。また, 球の 接触点での速度ベクトルが等しいという条件で，可動 子と小球間の回転伝達モデルと小球と出力球間の回転伝達 モデルを理論的に導いた。そして, 計測結果との比較から, 球支持用のボールキャスタの影響がなく, 可動子と出力球 間の回転伝達モデルとして用いることができることを確認 した。

本研究では，小球を一つ用いた球面減速機の可動子 と出力球間の回転伝達モデルを導出した。しかしながら,
小球が一つの場合，可動子の回転軸と小球の回転軸，あ るいは小球の回転軸と出力球の回転軸が一致すると回 転の伝達を行うことができないという問題がある。ま た，各球との接触面積が小さく，ボールキャスタのよ うな球を接触るものから摩擦の影響受けやすいという 問題もある。

今後は，それらの問題を解決するために，本論文で 導出した回転伝達モデルを基に，小球が二つ以上用い た球面減速機の回転伝達モデルの導出を行う。そして, 出力球の回転軸を明らかにして，小球を用いた球面減 速機の入出力トルクの比から減速比を求める。

\section{参考文献}

[1] 新世代アクチュエータの多自由度化可能性調査専門委員 会, 新世代アクチュエータの多自由度化可能性, 電気学 会技術報告, Vol.1265, 2012 .

[2] E.Onillon, O.Chételat, L.Rossini, L.Lisowski, S.Droz and J. Moerschell, Reaction Sphere for Attitude Control, Proceedings of 13th European space Mechanisms and Tribology Symposium, 2009.

[3] C.Cho, D.Kang, S.Kim, S.Won, and J.Lee, Using mathematical method of torque simulation for reducing calculation time of permanent magnet spherical wheel motor, Proceedings of the international Conference on Electrical Machines and Systems, pp.3112-3115, 2008.

[4] 矢野 智昭, 高トルク球面モータの開発 : 第 4 報:切頂八 面体と正十二面体に基づく球面ステッピングモータの提 案, 日本機械学会, 機素潤滑設計部門講演会講演論文集, Vol.8, pp.137-140, 2008.

[5] 五福 明夫, 単 万里, 柴田 光宣, 山西 輝裕, 亀川 哲志, 球面モ一夕駆動の撹拌器の開発, 日本機械学会論文集 C 編, Vol.77, No.778, pp.2400-2406, 2011.

[6] 角南 尚幸, 五福 明夫, 笠島 永吉, 矢野 智昭, 球面 減速機構における力伝達用小球の回転モデルの導出に関 する研究, 日本 AEM 学会, 電磁現象および電磁力に関す るコンファレンス講演論文集, pp.395-398, 2016.

[7] 独立行政法人産業技術照合研究所: 2010 産総研オープン ラボ研究カタログ, 球面モータと球面減速機構 http://www.aist.go.jp/digbook/openlab/2010/book.pdf (accessed June 22, 2015).

[8] 矢野 智昭, 球面加減速機構の設計, 日本機械学会, 年次 大会講演論文集，Vol.7，pp.247-248，2009.

[9] 笠島 永吉, 矢野 智昭, 芦田 極, 球面モー夕の開発（第 2 報: ロータの姿勢検出とフィードバック制御), 日本機 械学会, 日本機械学会論文集, Vol.80, No.809, p.DR0011, 2014. 